\title{
Penyuluhan Penyakit Tidak Menular (PTM) untuk Menumbuhkan Kesadaran Pencegahan pada Masyarakat di Desa Cipacing, Jawa Barat
}

\author{
Erna Herawati ${ }^{*}$, Yulia Sofiatin ${ }^{2}$ \\ ${ }^{1}$ Departemen Antropologi, FISIP, Universitas Padjadjaran \\ ${ }^{2}$ Departemen Ilmu Kesehatan Masyarakat, FK, Universitas Padjadjaran \\ Email: e.herawati@unpad.ac.id ${ }^{1}$,y.sofiatin@unpad.ac.id ${ }^{2}$ \\ *Corresponding author: e.herawati@unpad.ac.id ${ }^{1}$
}

\begin{abstract}
ABSTRAK
Angka prevalensi penyakit tidak menular (PTM) di Indonesia, termasuk di Desa Cipacing, Kecamatan Jatinangor, Kabupaten Sumedang, Provinsi Jawa Barat cukup tinggi. Namun, situasi ini belum diikuti perilaku kesehatan masyarakat untuk pencegahan meski mereka mengetahui dampak serius penyakit ini pada kehidupan mereka. Kegiatan sosialisasi mengenai pencegahan PTM ini bertujuan meningkatkan pengetahuan dan menumbuhkan kesadaran masyarakat pada pencegahan. Kegiatan ini dilakukan melalui sosialisasi (penyuluhan) dan pemeriksaan tekanan darah, gula darah, asam urat, dan kolesterol untuk mendeteksi dini risiko PTM. Hasil pemeriksaan menunjukkan bahwa sebagian besar warga di Desa Cipacing memiliki risiko tinggi pada PTM terutama penyakit tekanan darah tinggi. Kombinasi sosialisasi dan pemeriksaan untuk deteksi dini berdampak positif dalam membangun kesadaran para warga untuk melakukan pencegahan. Kegiatan ini juga mendorong masyarakat untuk melanjutkannya dalam kegiatan di Pos Pembinaan Terpadu (Posbindu) PTM di tingkat RW.
\end{abstract}

Kata Kunci: Penyuluhan, Pencegahan, Penyakit Tidak Menular

\section{Counseling on Non-Communicable Diseases (NCDs) to Raise Awareness of Prevention in the Community in Cipacing Village, West Java}

\begin{abstract}
The prevalence of non communibacle diseases (NCDs) in Indonesia is considerably high, including those in Cipacing village, Jatinangor sub-district, Sumedang District in the West Java Province. Despite this fact, there is low awareness of prevention among the villagers, eventhough they aware of the serious impact of the diseases towards their health and social-economic status. This activity aims at build awareness among villagers towards non-communicable diseases prevention. In this activity, combination of information dissemination and NCD scrining has effectively endorsed the villagers to build their awareness of the disease and has inspired them to initiate action for prevention. The scrining result showed that most of the villagers are at high risk of NCDs, in particular hypertension. This data have successfully endorsed the villagers to establish NCD scrining and mangement in their own neighborhood through Pos Pembinaan Terpadu (Posbindu) PTM, a community-based activity for NCD prevention and management.
\end{abstract}

Keywords: Information dissemination, Prevention, Non-communicable Diseases 


\section{PENDAHULUAN}

Penyakit tidak menular adalah penyakit yang disebabkan oleh gangguan metabolisme tubuh. Gangguan metabolisme disebabkan antara lain oleh 1)pola konsumsi tinggi karbohidrat, lemak, gula, tetapi kurang konsumsi sayur dan buah; dan 2)pola hidup yang kurang aktivitas fisik dan kurang olah raga; serta 3)depresi. Beberapa jenis penyakit tidak menular antara lain tekanan darah tinggi (hipertensi), kadar gula darah tinggi (diabetes mellitus), rematik dan nyeri sendi, jantung koroner, stroke, dan kanker (Kementrian Kesehatan Republik Indonesia, 2018).

Diantara penyakit tersebut, hipertensi paling banyak diidap oleh penduduk Indonesia usia dewasa $(>18$ tahun). Data hasil Riset Kesehatan Dasar (Riskesdas) 2018 Kementerian Kesehatan Republik Indonesia menunjukkan peningkatan prevalensi pada beberapa jenis penyakit tidak menular dewasa ini (Kementerian Kesehatan, 2018; Rossa, 2018). Prevalensi hipertensi (berdasarkan pengukuran pada penduduk berusia $>18$ tahun di Indonesia) meningkat pesat dalam lima tahun terakhir, dari 25.8 persen pada 2013, menjadi 31.4 persen pada 2018. Prevalensi Diabetes Mellitus (berdasarkan pengukuran pada penduduk berusia $>15$ tahun) juga mengalami peningkatan dari 6.9 persen pada 2013 menjadi 8.5 persen pada 2018 (Kementerian Kesehatan Republik Indonesia, 2018).

Penyakit tidak menular cenderung bersifat kronis, sulit diobati, dan sulit disembuhkan sehingga menurunkan kualitas hidup penderitanya. Selain itu, pengobatan yang lama seringkali mengakibatkan permasalahan keuangan bagi penderita dan keluarganya. Tindakan yang paling tepat untuk merespon penyakit tidak menular adalah pencegahan. Tindakan pencegahan yang dilakukan sejak usia dini terbukti paling efektif menghindarkan individu dari penyakit tidak menular. Saat ini, upaya pencegahan penyakit tidak menular telah dicanangkan pemerintah melalui program GERMAS (Gerakan Masyarakat Hidup Sehat) dan Pos Pembinaan Terpadu untuk pencegahan Penyakit Tidak Menular (Posbindu PTM) sejak 2016. Namun, meski program ini gencar dipromosikan selama beberapa tahun ini, tetapi belum menunjukkan hasil yang diharapkan (Abdusalam, 2017). Jumlah Posbindu di wilayah Indonesia masih sangat terbatas. Inisiatif dan partisipasi warga masyarakat dalam kegiatan pencegahan juga masih kurang. Hal ini terkait dengan kadar pemahaman masyarakat pada penyakit tidak menular. Sebagian besar masyarakat masih menganggap bahwa penyakit tidak menular seperti hipertensi, diabetes mellitus, jantung dan stroke adalah penyakit degeneratif yang wajar terjadi pada kalangan usia tua dan tidak dapat dicegah.

Kegiatan ini di latarbelakangi oleh tingginya prevalensi penyakit tidak menular dan kurangnya kesadaran warga masyarakat pada pencegahan penyakit tidak menular di Indonesia, khususnya di Provinsi Jawa Barat. Prevalensi penyakit tidak menular di Provinsi Jawa Barat cukup tinggi dalam beberapa tahun terakhir. Data Dinas Kesehatan Provinsi Jawa Barat 2012 menunjukkan bahwa dua penyakit tidak menular, tekanan darah tinggi dan stroke, menjadi alasan utama rawat inap pasien di seluruh rumah sakit di Jawa Barat (Agustina, 2016).

Kegiatan ini dilakukan di Desa

Cipacing, Kecamatan Jatinangor, Kabupaten Sumedang. Pada 2018, Kabupaten Sumedang menempati ranking kedua dari seluruh kabupaten di Provinsi Jawa Barat dalam jumlah kasus hipertensi. Kecamatan 
Jatinangor, salah satu dari 26 kecamatan di Kabupaten Sumedang, memiliki angka prevalensi hipertensi 37 persen pada 2015. Angka ini melebihi angka prevalensi di tingkat provinsi yaitu 29,4 persen dan nasional 25,8 persen (Sofiatin, Fihaya, Sukandar, dan Roesli, 2015).

Desa Cipacing, adalah salah satu dari 12 desa di Kecamatan Jatinangor, Kabupaten Sumedang, Provinsi Jawa Barat. Desa ini memiliki karakteristik desa-kota atau semi-urban dengan jumlah penduduk migran yang sangat besar. Migrasi ke wilayah desa ini antara lain disebabkan oleh aktivitas industri tekstil dan aktivitas pendidikan. Kecamatan Jatinangor menjadi kawasan pendidikan terpadu terbesar di Jawa Barat. Empat universitas negeri berada di wilayah ini: Universitas Padjadjaran, Institut Koperasi Indonesia, Institut Pendidikan dalam Negeri, dan Institut Teknologi Bandung.

Berdasarkan hasil survei mahasiswa program profesi ners Universitas Padjadjaran pada 2017, Desa Cipacing memiliki jumlah kasus penyakit tidak menular paling banyak dibanding 11 desa lain di Kecamatan Jatinangor. Lima penyakit yang mayoritas diidap warga antara lain hipertensi, asam urat, stroke, kanker, dan jantung koroner. Warga yang mengidap darah tinggi sebagian telah mengkonsumsi obat pengontrol tekanan darah. Namun tingkat kepatuhan mereka minum obat masih rendah. Seringkali, mereka tidak minum obat sesuai jadwal atau bahkan sengaja berhenti meminum obat karena mereka telah merasa sehat dan tidak memiliki keluhan yang mereka yakini berkaitan dengan darah tinggi, seperti pusing, sakit kepala, kaku kuduk, dan kesemutan. Selain itu, anggapan warga bahwa penyakit darah tinggi bukan penyakit berbahaya dan hanya penyakit biasa, turut membentuk rendahnya kesadaran mereka pada pencegahan dan kepatuhan pada pengobatan.

Kegiatan ini bertujuan meningkatkan pengetahuan warga tentang penyakit tidak menular dan menumbuhkan kesadaran warga untuk berperilaku hidup sehat agar terhindar dari penyakit tidak menular. Upaya meningkatkan pengetahuan ini sangat penting karena berdasarkan penelitian sebelumnya, ditemukan kaitan erat antara pengetahuan dengan perilaku kesehatan masyarakat. Misal, kaitan erat antara rendahnya pengetahuan masyarakat tentang penyakit Demam Berdarah dengan rendahnya kesadaran memberantas sarang nyamuk (Waris dan Yuana, 2013); kaitan erat antara pengetahuan ibu tentang imunasi dan perilaku memberikan imunisasi pada bayi mereka (Rizani, Hakimi, dan Ismail, 2009); kaitan erat antara pengetahuan keluarga dengan dukungannya pada kepatuhan berobat pasien Tuberkulosis (TB) paru (Dhewi, Armiyati, dan Supriyono, 2012); dan kaitan erat antara pengetahuan dan perilaku seks pranikah di kalangan siswa SMA (Aritonang, 2015).

Cara untuk meningkatkan pengetahuan, salah satunya dengan sosialisasi. Sosialisasi adalah proses penanaman norma dan ideologi pada individu anggota masyarakat dengan tujuan agar individu mengenal dan mengadopsi nilai-nilai sosial di kelompok ia tinggal. Sosialisasi meliputi dua proses yaitu pembelajaran dan pengajaran mengenai norma dan ideologi (Macionis, 2013; Koentjaraningrat, 2009). Di dalam konteks kesehatan masyarakat, konsep sosialisasi merujuk pada upaya pemindahan informasi mengenai pencegahan dan penanggulangan penyakit yang dilakukan melalui kegiatan-kegiatan penyuluhan. 
Kegiatan pengabdian masyarakat ini didanai oleh Universitas Padjadjaran, dalam skema kegiatan pengabdian masyarakat yang terintegrasi dengan hibah riset fundamental (RFU).

\section{METODE PENELITIAN}

Desa Cipacing terdiri atas 18 Rukun Warga (RW). Namun, kegiatan pos pembinaan terpadu untuk pencegahan penyakit tidak menular (Posbindu PTM) baru dirintis di delapan RW saja. Kegiatan pengabdian ini dilakukan secara intensif di dua RW di Desa Cipacing yang belum memiliki kegiatan Posbindu PTM yaitu RW 16 dan RW 18. Kegiatan dilakukan pada Juni - November 2018.

Pelaksana kegiatan ini adalah tim pengabdian masyarakat yang terdiri atas dosen dan mahasiswa dari Prodi Antropologi Fakultas Ilmu Sosial dan Ilmu Politik dan Fakultas Kedokteran Universitas Padjadjaran, bidan desa yang bertugas di RW 16 dan 18, para ketua RW, para kader kesehatan, para tokoh agama di dua RW (ustadz), dan para warga yang bertempat tinggal di dua wilayah RW tersebut.

Kegiatan pengabdian ini didahului dengan penyebaran undangan pada para warga. Undangan dibuat dalam versi cetak yang ditempel di setiap gang di RW, versi elektronik yang disebarluaskan oleh kader kesehatan melalui group media sosial di setiap RW, dan versi lisan yang disampaikan oleh ustadz saat acara pengajian dan melalui pengeras suara di masjid, serta disampaikan dari rumah ke rumah oleh kader kesehatan (gambar 1).

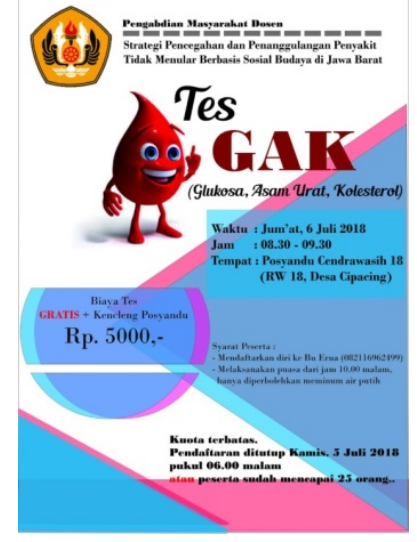

Gambar 1. Undangan kegiatan

Setiap paket kegiatan pengabdian dilakukan dalam 2 hari. Kegiatan hari pertama dilakukan pada sore hari, dan hari kedua di pagi hari. Kegiatan hari pertama berisi sosialisasi tujuan kegiatan pengabdian, pemberian informasi mengenai penyakit tidak menular, serta pendaftaran peserta pemeriksaan kesehatan yang akan dilakukan di hari kedua.

Pada akhir acara di kegiatan di hari pertama, warga yang berminat untuk mengikuti pemeriksaan kesehatan, mendaftarkan diri pada tim pengabdian. Calon peserta juga menerima penjelasan mengenai persiapan mengikuti pemeriksaan kesehatan. Mereka disarankan berpuasa mulai pukul 10 malam (tetapi boleh meminum air putih) dan diminta hadir di tempat pemeriksaan antara pukul 6-8 keesokan pagi.

Pada kegiatan ini juga dilakukan pre-test dan post-test; tetapi tidak menggunakan model selfadministered quistionaire. Pre-test dilakukan dengan cara mewawancarai beberapa warga yang hadir di acara penyuluhan mengenai motivasi mereka hadir di acara penyuluhan; dan hal-hal apa saja yang mereka ketahui mengenai penyakit tidak menular. Post-test dilakukan dengan cara yang sama, yaitu mewawancarai warga mengenai pengetahuan mereka tentang PTM dan opini mereka mengenai manfaat 
kegiatan. Hasil wawancara ini diperlakukan sebagai data pre-test dan post-test untuk menggambarkan perubahan tingkat pengetahuan dan manfaat kegiatan bagi warga. Wawancara hanya dilakukan pada warga yang menyatakan bersedia.

\section{HASIL DAN PEMBAHASAN}

Kegiatan di RW 16 bertempat di Masjid Jami Al Hikmah dan dilakukan setelah acara pengajian rutin di RW tersebut. Sedangkan di RW 18, kegiatan bertempat di rumah warga. Peserta yang hadir di setiap RW berkisar 50 orang. Sebenarnya jumlah warga yang ingin hadir dalam acara penyuhan dapat melebihi 50 orang akan tetapi jumlah terpaksa dibatasi karena keterbatasan kapasitas tempat. Pada saat acara sosialiasi para warga mengisi daftar hadir dan menerima satu lembar leaflet yang dibuat oleh tim pengabdian. Isi leaflet adalah penjelasan singkat mengenai penyakit tidak menular, jenis-jenisnya, gejalanya, penyebabnya, cara pencegahannya; dan faktor resikonya (gambar 2).

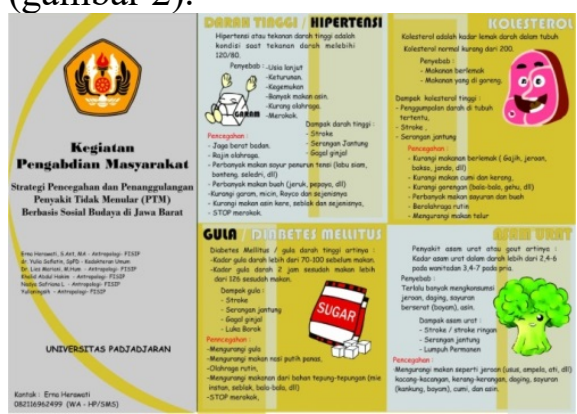

Gambar 2: Leaflet

Selain mendapatkan informasi tertulis dari leaflet, warga juga menerima informasi secara lisan dari ketua tim pelaksana. Penjelasan lisan dibantu tayangan power point. Kegiatan sosialisasi berlangsung interaktif dalam bentuk obrolan dan diskusi santai antara tim dengan warga (gambar 3). Model sosialisasi ini dimaksudkan untuk membuat warga lebih rileks dan antusias bertanya dan mendiskusikan masalah penyakit tidak menular.

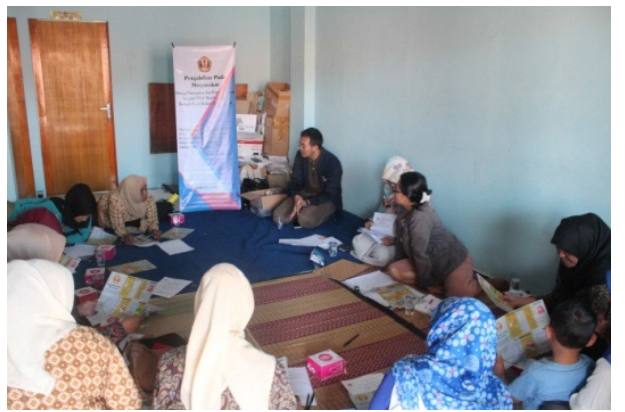

Gambar 3: Kegiatan Sosialiasi

Warga yang hadir di acara sosialisasi kebanyakan mengaku belum memiliki pengetahuan yang memadai tentang penyakit tidak menular. Akibatnya, mereka tidak menyadari risiko yang ditimbulkan penyakit tersebut. Mereka juga menyatakan bahwa mereka tidak mengetahui cara melakukan pencegahan yang tepat. Pada acara sosialiasi ini, beberapa warga yang memiliki kerabat yang mengidap salah satu penyakit tidak menular bahkan memanfaatkannya sebagai wadah untuk konsultasi kesehatan dengan tim pengabdian.

Di akhir kegiatan sosialisasi, hampir semua peserta yang hadir, berminat untuk mengikuti pemeriksaan kesehatan di keesokan harinya. Beberapa warga bahkan berkeinginan mendaftarkan kerabatnya yang tidak dapat dapat hadir di kegiatan sosialisasi untuk ikut pemeriksaan kesehatan. Namun, tim pengabdian tidak dapat mengakomodasi permintaan tersebut karena keterbatasan jumlah alat tes.

Pada akhir kegiatan sosialisasi, beberapa warga yang bersedia di wawancara menuturkan bahwa mereka mengaku baru mendapatkan informasi rinci mengenai penyakit tidak menular di kegiatan sosialisasi tersebut.

"Saya sering denger sih tentang tensi-tensi dan penyakit gula. Tapi 
kurang tahu gejalanya bagaimana dan apa bisa diobati atau tidak. Saya ingin tahu tentang itu. Ya buat pengetahuan gitu. Kan kalau sudah tahu, bisa antisipasi gitu. Makanya pas dikasih tahu sama Ibu Kader ada acara ini saya tertarik hadir" (Pernyataan Ibu Eti, warga RW 18

"Bener ada manfaatnya penyuluhan gini. Ya sekarang jadi saya ada info tentang penyakit tidak menular itu. Jadi agak takut ya sama akibatnya, Tapi bagus juga jadi tahu mesti gimana kalau ada sodara atau kita sendiri mengalaminya. Tapi ya memang lebih pasti kalau diukur ya, makanya besok saya mau ikut diperiksa darah" (Pernyataan Ibu Eti setelah mengikuti penyuluhan.

Selain mengkonfirmasi manfaat sosialisasi, pernyataan Ibu Eti menggambarkan perubahan kadar pengetahuannya mengenai penyakit tidak menular sebelum dan setelah ia mengikuti sosialisasi. Ia menjadi paham dan tahu cara mencegahnya.

Agenda kegiatan di hari kedua, yaitu pemeriksaan kesehatan yang dimulai pada pukul 6.00 WIB pagi. Kegiatan di RW 18 bertempat di lapangan voli dan kegiatan di RW 16 bertempat di halaman masjid. Antusiasme warga pada pemeriksaan kesehatan sangat tinggi. Mereka hadir di tempat kegiatan sejak pukul 5.30 WIB pagi. Para mahasiswa dari Prodi Antropologi bertugas mengelola pendaftaran ulang peserta, pemeriksaan fisik (tinggi badan, berat badan, lingkar perut. Bidan desa bertugas memeriksa tekanan darah, dan para mahasiswa kedokteran bertugas mengambil sampel darah dan konseling pada warga saat mengambil hasil pemeriksaan.

Pemeriksaan gula darah, asam urat, dan kolesterol dilakukan dengan metode rapid test menggunakan alat dengan merk Easy Touch GCU (Glucose, Cholesterol, Uric Acid). Waktu yang diperlukan untuk mengukur kadar gula darah dan asam urat cukup singkat yaitu 10-15 detik. Namun, waktu yang diperlukan untuk mengukur kadar kolesterol agak lama, yaitu 1-2 menit per orang.

Hasil pemeriksaan kesehatan pada warga di kedua RW tampak dalam tabel 2 dan 3 sebagai berikut :

Tabel 2. Rekap hasil deteksi dini PTM RW 18 Desa Cipacing $(\mathrm{n}=50$ Jiwa (dewasa $>20$ tahun)

\begin{tabular}{|c|c|c|}
$\begin{array}{l}\text { Angka Hasil Tes } \\
\text { > normal }\end{array}$ & Frekuensi & Persentase \\
\hline Kolesterol & 18 & $36 \%$ \\
\hline Tekanan darah & 11 & $22 \%$ \\
\hline Asam Urat & 2 & $4 \%$ \\
\hline Glukosa puasa & 6 & $12 \%$ \\
\hline Angka hasil normal & 13 & $26 \%$ \\
\hline
\end{tabular}

Sumber: Rekap data hasil pemeriksaan RW 18, 2018

Tabel 3. Rekap hasil deteksi dini PTM RW 16 Desa Cipacing $(\mathrm{n}=50$ Jiwa (dewasa $>20$ tahun)

\begin{tabular}{|c|c|c|}
$\begin{array}{l}\text { Angka Hasil Tes } \\
\text { > normal }\end{array}$ & Frekuensi & Persentase \\
\hline Kolesterol & 10 & $20 \%$ \\
\hline Tekanan darah & 14 & $28 \%$ \\
\hline Asam Urat & 8 & $16 \%$ \\
\hline Glukosa puasa & 7 & $14 \%$ \\
\hline Angka hasil normal & 11 & $22 \%$ \\
\hline
\end{tabular}

Sumber: Rekap data hasil pemeriksaan 2018

terangkum pada tabel diatas menunjukkan bahwa sebagian besar warga di RW 16 dan RW 18 yang mengikuti pemeriksaan terdeteksi memiliki risiko yang tinggi pada penyakit tidak menular.

Hasil pemeriksaan kesehatan direkap pada sebuah kertas kecil dan langsung diberikan pada warga. Setelah menerima hasil tes, warga dipersilakan menuju meja konseling. Salah satu anggota tim pengabdian bertugas sebagai konselor untuk memberikan penjelasan pada warga mengenai hasil pemeriksaan kesehatan mereka. Warga menggunakan sesi konseling untuk 
berdiskusi dengan tim konseling mengenai status kesehatan mereka, terutama terkait penyakit tidak menular. Seringkali konseling tidak berlangsung satu demi satu, tetapi secara berkelompok. Pada kesempatan tersebut diskusi antar warga mengenai status kesehatan mereka pun terjadi. Para warga yang semula mengira bahwa mereka tidak beresiko PTM menjadi sadar akan resiko tersebut setelah mereka melihat hasil pemeriksaan. Misal, Ibu Rosita warga RW 18 berusia 50 tahun yang baru mengetahui bahwa tekanan darahnya cukup tinggi, 190/110 mm Hg:

"Saya sebelumnya ga pernah tahu berapa ukuran tekanan darah yang normal. Kirain saya sehat-sehat aja. Ternyata saya baru tahu kalau tekanan darah saya tinggi, Harusnya kan dibawah 130 atau 120 ya "(Pernyataan Ibu Rosita, )

Selain menyediakan informasi mengenai status kesehatan pada warga yang belum pernah mengetahui dirinya beresiko PTM, kegiatan pemeriksaan kesehatan juga memberi manfaat bagi para warga yang telah mengidap salah satu PTM untuk memonitor status kesehatan mereka. Misal, Pak Obar, ustadz di RW 18 berusia 61 tahun; ia menyatakan:

"Adanya tes ini membuat saya jadi tahu kondisi saya saat ini. Saya pernah kena derita stroke ringan sampai dirawat di RSU Sumedang. Sejak pulang dari RS saya belum pernah cek lagi. Sekarang baru saya tahu, ternyata tensi saya masih tinggi; 150. Kata si Neng dokter, ini bahaya ya buat stroke. Saya juga ada asam urat tinggi, 7.5. Kan saya jadi tahu kalau begini" (Pernyataan Pak Obar)

Pada hari pemeriksaan, banyak warga yang tidak mendaftar sebelumnya pun turut hadir di tempat pemeriksaan dan berharap dapat mengikuti pemeriksaan kesehatan. Tim pengabdian akhirnya memberikan penjelasan pada kelompok warga tersebut bahwa jumlah alat yang tersedia untuk pemeriksanaan darah sangat terbatas. Namun, tim menyediakan layanan pemeriksaan lain, misal pengukuran untuk tekanan darah dan pemeriksaan fisik bagi kelompok warga tersebut.

Pada akhir kegiatan pemeriksaan Kesehatan, beberapa warga yang diwawancarai oleh anggota tim pengabdian menyatakan pendapat mereka mengenai dampak dari kegiatan pengabdian ini:

'Saya bener-bener berterima kasih ya dengan adanya kegiatan ini. Benar-benar terasa manfaatnya. Biasanya kan kalau warga cuma diberi penyuluhan aja ya pulangnya sudah lupa. Apalagi yang merasa gak punya penyakit itu, ya cuek aja. Tapi kalau diteruskan sama pemeriksaan kan lebih baik, jadinya kita tahu, kita bakal kena penyakit itu apa enggak. Pemahaman tuh jadi lebih nempel di kepala. Alhamdulillah sih saya sehat, semua dibawah normal. Tapi kan saya jadi tahu kalau saya nggak boleh lengah. Tetap aja harus jaga kesehatan" (Pak Sutisna warga $R W 16$ )

"Saya suka banget kegiatan kayak gini. Gak cuma penyuluhan yang omong-omong saja tapi ada tesnya, jadi kan kita tahu ada resiko atau enggak. Misal ada resiko jadi waspada. Cara kayak gini lebih baik daripada cuma omong-omong doang. Nah, ini tadi saya baru tahu kalau saya ternyata asam urat hahaha Padahal saya paling suka makan jengkol." Pak Dedih, warga $R W$ 18)

Pernyataan Pak Sutisna dan Pak Dedih menunjukkan adanya perubahan pengetahuan mereka sebelum dan setelah mereka ikut kegiatan pengabdian. Keduanya menyatakan bahwa kegiatan 
penyuluhan memberikan pengetahuan pada mereka mengenai penyakit tidak menular; sementara kegiatan deteksi dini menumbuhkan pemahaman mereka pada penyakit tidak menular.

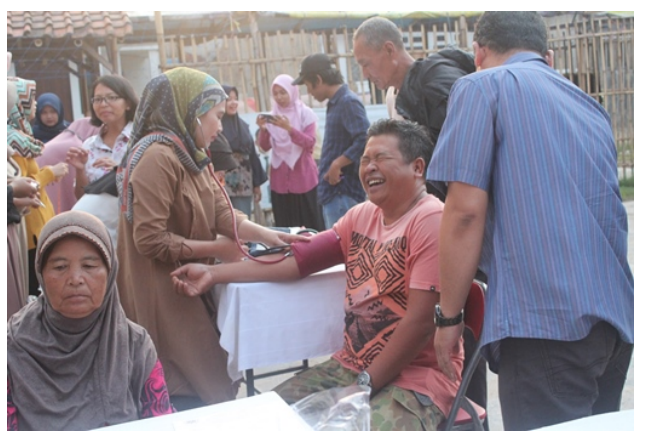

Gambar 4. Kegiatan pemeriksaan

Kesehatan untuk deteksi dini PTM

Kegiatan deteksi dini

memberikan dampak yang sangat besar pada tumbuhnya kesadaran warga akan pentingnya melakukan pencegahan. Namun, meski dampaknya sangat berarti untuk meningkatkan pemahaman warga, pelaksanaan kegiatan deteksi dini memerlukan dana yang cukup besar untuk membeli alatalat tes. Selain ketersediaan alat tes, tantangan lain dari kegiatan pengabdian ini adalah partisipasi warga dan dukungan para perangkat desa. Partisipasi warga pada kegiatan pengabdian ini sangat baik. Hal ini ditunjukkan oleh banyaknya jumlah warga yang ingin turut serta baik dalam kegiatan penyuluhan maupun skrining. Para perangkat desa juga sangat mendukung kegiatan ini, bahkan para kader dan bidan pun mengambil peran dalam kegiatan ini.

Para kader di kedua RW pun sepakat untuk melanjutkan kegiatan penyuluhan dan deteksi dini PTM secara rutin setelah kegiatan pengabdian selesai. Mereka akan bekerjasama dengan bidan desa dan Puskesmas. Meski mereka tidak dapat melakukan tes darah, mereka sepakat untuk memeriksa tekanan darah dan berat badan saja. Kegiatan ini akan dilakukan bersamaan dengan kegiatan Posyandu Balita. Inisiatif para kader menunjukkan bahwa kegiatan ini telah berhasil mendorong kesadaran pada kader untuk lebih berperan aktif dalam kegiatan pencegahan PTM di wilayahnya masing-masing.

\section{SIMPULAN}

Kegiatan sosialisasi dan pemeriksaan kesehatan untuk deteksi dini penyakit tidak menular efektif meningkatkan pengetahuan dan kesadaran masyarakat untuk menerapkan perilaku hidup sehat. Kegiatan ini dapat dilanjutkan sendiri oleh masyarakat setelah kegiatan pengabdian selesai. Di masyarakat terdapat para warga yang potensial untuk melakukannya yaitu kader kesehatan, bidan, karang taruna, pemuka agama atau warga lain yang antusias untuk berpartisipasi. Apabila kegiatan deteksi dini penyakit tidak menular melalui rapid test dengan darah memerlukan biaya, warga akan diminta membayar biaya pengganti pembelian alat tes yang digunakan. Keberlanjutan kegiatan pencegahan penyakit tidak menular ini akan menjadi salah satu jalan untuk menurunkan angka prevalensi penyakit tidak menular di Desa Cipacing.

\section{DAFTAR PUSTAKA}

Abdusalam, MS. 2017. Tiga Daerah di Jabar Ini Dinilai Miliki Gerakan Masyarakat Sehat Terbaik. http://jabar.tribunnews.com/2017/ 11/09/3-daerah-di-jabar-inidinilai-miliki-gerakan-masyarakatsehat-di-terbaik.

Agustina, A. 2016. angka kematian akibat penyakit tidak menular semakin meningkat. https://bandung.merdeka.com/gayahidup/angka-kematian-akibatpenyakit-tidak-menular-semakinmeningkat-161129h.html. 
Aritonang, T. R. 2015. Hubungan

Pengetahuan dan Sikap Tentang

Kesehatan Reproduksi dengan

Perilaku Seks Pranikah Pada

Remaja Usia (15-17 Tahun) di SMK Yadika 13 Tambun, Bekasi. Jurnal Ilmiah Widya, 1(1).

Dhewi, G. I., Armiyati, Y., Supriyono, M. 2012. Hubungan antara Pengetahuan, Sikap Pasien dan Dukungan Keluarga dengan Kepatuhan Minum Obat pada Pasien TB paru di BKPM Pati. Karya Ilmiah S. 1 Ilmu Keperawatan.

Kementrian Kesehatan Republik Indonesia.2018. Hasil Utama Riskesdas 2018. Retrieved Januari 20, 2019, from Depkes.go.id: www.depkes.go.id/...2018/Hasil\%2 0Riskesdas\%202018.pdf

Koentjaraningrat.2009. Pengantar Ilmu Antropologi. Jakarta: Rineka Cipta

Macionis, J. 2013. Sociology. Singapore: Perason Education.

Rizani, A., Hakimi, M., Ismail, D. 2009. Hubungan pengetahuan, sikap dan perilaku ibu dalam pemberian imunisasi hepatitis B 07 hari di Kota Banjarmasin. Berita Kedokteran Masyarakat, 25(1), 12.

Rossa, V. 2018. November 2. https://www.suara.com/healtHasil Riskesdas 2018 Penyakit Tidak Menular Semakin Meningkat. Retrieved Januari 26, 2019, from suara.com:

https://www.suara.com/health/201 8/11/02/101437/hasil-riskesdas2018-penyakit-tidak-menularsemakin-meningkat

Sofiatin, Y., Fihaya, F. O., Sukandar, H., Roesli, R. 2015. Prevalence of Hypertension and Its Complication in Jatinangor. Journal of Hypertension, 33-35. 